AperTO - Archivio Istituzionale Open Access dell'Università di Torino

\title{
Kant and Historical Knowledge
}

\section{This is the author's manuscript}

Original Citation:

Availability:

This version is available http://hdl.handle.net/2318/136263

since 2016-10-01T18:08:43Z

Terms of use:

Open Access

Anyone can freely access the full text of works made available as "Open Access". Works made available under a Creative Commons license can be used according to the terms and conditions of said license. Use of all other works requires consent of the right holder (author or publisher) if not exempted from copyright protection by the applicable law. 
This is an author version of the contribution published on:

Questa è la versione dell'autore dell'opera:

Massimo Mori, Kant and the Historical

Knowledge, in

Graduate Faculty Philosophy

Journal, vol. 34, n. 1, 2013, pp. 2142, ISSN 0093-4240

The definitive version is available at:

La versione definitiva è disponibile alla URL: www.newschool.edu/nssr/GFPJ 
Massimo Mori

\section{KANT AND HISTORICAL KNOWLEDGE}

It is common knowledge that the philosophy of history is not a marginal episode in Kantian thinking. Yet the eagerness not to relapse into this historiographical prejudice has often caused interpreters to commit the opposite error of searching at all costs for its absolute internal coherence and its complete adherence to the transcendental "system", understood in turn as a compact doctrinal corpus. Kant's philosophy of history, perhaps more than other parts of his thought, presents conceptual difficulties, arising from questions of internal consistence as well as from the demand to incorporate into the transcendental system requirements originating from different cultural traditions. One of these shady areas is the epistemological status of historical knowledge, understood not as the historiographical reconstruction of specific occurrences ("history proper, that of empirical composition"), but rather as the overall understanding of the meaning and orientation of the historical process (from the point of view of a "philosophical mind") ${ }^{1}$. This is a problem of great relevance as it concerns fundamental questions of Kantian reflection on history, such as the relationship between finality and causality, or between freedom and necessity. In regards to this problem I reckon that Kant draws on three forms of knowledge (for reasons which will be expounded upon): regulative, constitutive and normative in ethical sense. The term "knowledge" here must be taken in the broadest sense and not strictly Kantian, as a generic form of knowledge which includes determinant judgment (in which constitutive "knowing", strictly speaking, is quite different from mere "thinking"), reflective judgment (which still expresses a theoretical dimension of knowledge, though devoid of constitutive value), and moral judgment (which is founded upon a synthetic process a priori of the pure reason in its

${ }^{1}$ Cf. Idee zu einer allgemeinen Geschichte der Menschheit, VIII, 30, 30-32 (Kant, Political Writings, ed. by H. Reiss, Cambridge, Cambridge University Press, 1770, p. 53). Kant's works are always cited with reference to the Academie-Ausgabe: Gesammelte Schriften, Berlin-Leipzig, de Gruyter. 1910-. As per usual, the Roman numeral indicates the volume, and the Arabian numerals the page(s) and the line(s). 
practical employment). In regards to the general framework of the philosophy of history and of its placement in the overall context of Kantian thought, these three forms of knowledge-which are, let it not be forgotten, different expressions of the very same reason-appear mainly complementary, and in some way each of them takes part in the realization of the others. This does not mean, however, that all clashes, dissonances or juxtapositions among the various levels are overcome. In the interpretation which I am proposing a complete convergence can only be found in one point.

1. Constitutive knowledge and regulative knowledge - It is a universally shared view that Kant's philosophy of history must be read in the light of the Critique of Judgment ${ }^{2}$. This is primarily because, as is known, Kant himself offers a brief but effective synthesis of it in $\S 83$ of the third Critique, providing precise coordinates for its position in the framework of the already completed transcendental system. But above all-and as a consequence-the point of view of the Critique of Judgment proves indispensable because without a reference to the theory of reflective judgment it is impossible to understand the relation that, in the historical process, is entertained by conceptual pairs such as causal mechanism and final destination, natural necessity and moral freedom, the phenomenal world of historical occurrences and the noumenal reality to which it refers. An example, which is not worth dwelling on due to its notoriety, is that any understanding of Kantian philosophy of history is precluded without reference to $\S \S 80-81$, relative to the relationship between the principle of mechanism and the principle of finality: the former is subordinated to the later as soon as one shifts from the constitutive to regulative knowledge. Yet it is clear that a form of regulative knowledge has already been present since Kant's first writing on history, Idee zu einer allgemeinen Geschichte in weltbürgerlicher Absicht (Idea for a Universal History with a Cosmopolitan Purpose). Being from 1784, this work is still well

\footnotetext{
${ }^{2}$ In reality, this position has existed from the very first interpretations of Kantian philosophy of history: cf. F. Medicus, Kants Philosophie der Geschichte, "KantStudien", VII, 1902, pp. 1-22, 171-299; though it became an inevitable starting point for each study regarding the topic, beginning with the works of G. Lehmann, System und Geschichte in Kants Philosophie, "II pensiero", III, 1958, 14-34; F. Kaulbach, Der Zusammenhang zwischen Naturphilosophie und Geschichtsphilosophie bei Kant, "Kant-Studien", LVI, 1966, pp. 430-51 and especially after K. Düsing's classic study, Die Teleologie in Kants Weltbegriff, Bonn, Bouvier, 1968, pp. 217-28.
} 
away from the definition of the reflective function of judgment, which Kant will reach, especially with regards to his teleological application, in the late seventeen-eighties ${ }^{3}$. The term Idee, which appears in the very title of the work, is not to be understood in a traditional sense, but rather in the transcendental sense of a concept of an unconditional totality, which falls out of experience; in this case, the totality of history. This does not indicate a knowable object, but rather, in a purely normative form, "an idea of how world events must develop if they are to conform to certain rational ends" ${ }^{4}$. In the work, the expression "Leitfaden" ("guide", "rule") frequently appears (and once the expression "a priori Leitfaden"5), to suggest that the function of the philosophy of history is to apply single occurrences to an overall order, in such a way that what is empirically a mere "aggregate" of facts can be represented as a rational "system." The "purpose in nature" (Naturabsicht) or the "hidden plan of nature" (VIII, 27, 3), to which Kant often refers, has nothing to do with the "cunning" of Hegelian reason"; nor is it the result of a necessary causal process that can be scientifically reconstructed, as various interpreters from the early twentieth century liked to claim ${ }^{7}$.

Amid Idea and the most mature expression of Kantian philosophy of history, the second part of Der Streit der Fakultäten (The Conflict of the

${ }^{3}$ Cf. J. H. Zammito, The Genesis of Kant's Critique of Judgement, Chicago, University of Chicago Press, 1992, pp. 7-8.

${ }^{4}$ VIII, 29, 7-8; Political Writings, p. 51. P. Chiodi was among the first to focus on the transcendental meaning of the term "idea" in the work from '84 in his La filosofia kantiana della storia, "Rivista di filosofia", LVIII, 1967, pp. 263-287, specifically p. 278.

${ }^{5}$ VIII, 30, 29; Political Writings, p. 53: "A priori rule".

${ }^{6}$ VIII, 18,8 and 27, 3; Political Writings, pp. 42 and 53. The comparison with Hegel was proposed, amongst others, by L. Landgrebe, Die Geschichte im Denken Kants, "Studium generale", VII, 1954, p. 536; K. Weyand, Kants Geschichtsphilosophie: Ihre Entwicklung und ihr Verhältnis zur Aufklärung, Köln, Kölner Universitätsverlag, 1963, pp. 43-44; M. Despland, Kant on History and Religion, Montreal, McGill-Queen's University Press, 1973, pp. 55 e 70; F. Kaulbach, Welchen Nutzen gibt Kant der Geschichtsphilosophie?, "Kant-Studien”, LXVI, 1975, p. 67.

${ }^{7}$ These interpretations are strongly conditioned by theoretical premises; of positivist nature in the case of $\mathrm{K}$. Lamprecht, Herder und Kant als Theoretiker der Geschichtswissenschaft, "Jahrbücher für Nationalökonomie und Statistik", LXIX, 1897, pp. 161-203, or ascribable to "neo-Kantian socialism" in the case of K. Vorländer, Introduction to I. Kant, Kleinere Schriften zur Geschichtsphilosophie, Ethik und Politik, Leipzig, Meiner, 1913, or of M. Adler, Kant und der Sozialismus (1904), in Kant und der Marxismus. Gesammelte Aufsätze zur Erkenntniskritik und Theorie des Sozialen, Berlin, Laub, 1925, pp. 83-132. 
Faculties) from 1798, we find continuity in the name of regulative knowledge. This does not mean, however, that nothing had changed in almost fifteen years. While the Critique of Judgment will inspire the historical-philosophical writings of the seventeen-nineties, the model of regulative knowledge in the work from '84 is still offered by the Transcendental Dialectic of the Critique of Pure Reason, whose first edition precedes Idea by three years. The idea can assume a practical function, as shown by the reference to Plato found in Section I of Chapter I of the Dialectic. The speculative ideas themselves, moreover, "may perhaps make possible a transition from the concepts of nature to the practical concepts, and in that way may give support to the moral ideas themselves, bringing them into connection with the speculative knowledge of reason"8. Similarly, the telos that Idea assigns to the historical process allows us to speak of a "chiliasm" in history, which, though it does not guarantee theoretical certainties, promotes man's "approximation" towards the practical objective in an asymptotic way ${ }^{9}$. However, in the Transcendental Dialectic of the first Critique the regulative function of the idea is considered in its theoretical quality of guiding concept of constitutive knowledge, more so than in its practical quality. The problem is bringing the multiple forms of knowledge back to the unity of the system. The single piece of knowledge, in fact, despite being determined by the a priori principles of intellect, is not per se combined to other ones through systematic connections.

This unity of reason always presupposes an idea, namely, that of the form of a whole of knowledge -- a whole which is prior to the determinate knowledge of the parts and which contains the conditions that determine a priori for every part its position and relation to the other parts ${ }^{10}$.

There is no reason, then, to exclude the notion that this theoretical and systematical function, too, together with the practical function, is relevant in Idea. It is no accident that in this work Kant undeniably attributes a primary role to constitutive knowledge (founded on the causal synthesis of experience) not only in the reconstruction of empirical history, which he

\footnotetext{
${ }^{8}$ A 329 = B 386 (Critique of Pure Reason, translated by N. Kemp Smith, LondonNew York, Macmillan-St. Martin Press, 1929, p. 320).

${ }^{9}$ VIII, 23, 24; Political Writings, p. 47. Cf. also VIII, 27, 1-13

${ }^{10}$ A $645=$ B 673 (Critique of Pure Reason, p. 534).
} 
mentions briefly in closing, but also in the philosophy of history. This type of knowledge cannot be excluded from the historical world, since human actions, which constitute its object, "are determined in accordance with natural laws, as is every other natural event" ${ }^{\prime 1}$. The problem, then, is not found in contrasting constitutive knowledge of nature against regulative knowledge of history, but rather in realizing a synergy between constitutive and regulative knowledge, just as it occurs in the natural sciences. As a result, the idea of an overall meaning permits historical-causal knowledge to proceed. The proposition of a regulative guiding thread does not seem so incompatible with the hope that one day a Kepler or a Newton will come to life for history, too; based on such a regulative principle, they will give it an entirely causal explanation according to "definite laws", just as the real Kepler and Newton (or even Kant himself in the Universal Natural History and Theory of Heaven from 1755) did with astronomy ${ }^{12}$. The emerging statistical science, which is mentioned in Kant's writings on race and in his Anthropology from a Pragmatic Point of View, proposed the possibility of detecting methodical analogies between historical knowledge and the natural sciences. Certain uniformities or regularities of social phenomena (trends in marriage or in death considered in the long term) ${ }^{13}$ appeared to be especially relevant to empirical laws. In both science and history one could think of increasingly broad generalizations and increasingly vast taxonomic hierarchies that, despite remaining within possible and conditioned experience, could prefigure laws capable of totally explaining a whole class of phenomena (as is the case with Newton's law of gravity, for example).

In Idea, however, the relationship between causality and finality (and, therefore, between constitutive and normative knowledge) is not entirely clear. In certain passages the need to acknowledge a cognitive dimension of the philosophy of history makes the teleological perspective assume an almost determinant character, which draws it near natural causality. For instance, in Propositions I and II, the "teleological theory of nature" is traced back to the development of pre-existing "germs" (Keime) in man. This concept oscillates

\footnotetext{
${ }^{11}$ VIII, 17, 3-4; Political Writings, p. 41.

${ }^{12}$ Cf. VIII, 18, 9-17; Political Writings, p. 42.

${ }^{13}$ Cf, VIII, 17, 12-21; Political Writings, p. 41.
} 
ambiguously between final and efficient causality, which also occurs in epigenetic theories deriving from Blumenbach, from which Kant drew inspiration. Similarly, the finality of the succession of generations-which was, pour cause, much to the dismay of Herder $^{14}$-appears to make reference to the Enlightenment doctrine of progress as mechanical (causal) accumulation of knowledge and civilization, more so than to a transcendental concept of ends.

The relative obscurity of the relationship between causality and finalism in Idea, however, is due to a more structural reason, which reflects a difficulty that is already present in the Critique of Pure Reason and exceeded only in the third Critique. Both Critiques face the problem of the systematic unity of the knowledge of nature, understood as the organic relation of the multiple natural phenomena to the one system of science, as well as the unity of the empirical and particular laws of science and the a priori and universal laws of nature. In both cases, therefore, the possibility of a teleological interpretation of nature is involved: through the doctrine of ideas in the Transcendental Dialectic in the first Critique, and through the doctrine of teleological judgment in the third. Yet, methodologically, natural finality is understood in two very different senses ${ }^{15}$. In the Dialectic of Pure Reason (but also in the so-called

\footnotetext{
${ }^{14} \mathrm{Cf}$. the familiar mention, which is implicitly polemic toward Kant, in the second part of Ideen zur Philosophie der Geschichte der Menschheit, I. VIII, ch. V: "what could it mean to say [...] that all generations are made for the last generation, which sits enthroned on the decayed frame of the happiness of all previous ones?" (J.G. Herder, Werke in zehn Bänden, vol. VI, edited by M. Bollacher, Frankfurt am Main, Deutscher Klassiker Verlag, 1989, p. 332). Cf. also the acrimonious tone in the letter to Hamann from February 14, 1785 in which Herder, referring to Kant, ironically states that he has no use for "his childish plan according to which the human being is created for the species and the most perfect state-machine at the end of time"(J.G. Hamann, Briefwechsel, edited by W. Ziesemer and A. Henkel, 7 vol., Wiesbaden, Insel Verlag, 1955-79, V, p. 363).

${ }^{15}$ For more on this, cf. J. D. Mc Farland, Kant's Concept of Teleology, Edinburgh, University of Edinburgh Press, 1980, pp. 18-24 e 32-42. On the consequences that the various systematic conceptions from the first and third Critiques have on Kantian philosophy of history cf. P. Kleingeld, Fortschritt und Vernunft: Zur Geschichtsphilosophie Kants, Würzburg, Königshausen \& Neumann, 1995, ch. VII. Kleingeld also has the merit of having insisted upon the theoretical value of Kantian philosophy of history in opposition to the interpretations that only acknowledge the practical aspect (an extreme position apropos is that of W.J. Booth, Interpreting the World: Kant's philosophy of history and religion, Toronto-Buffalo-London, University of Toronto Press, 1986, which traces Kant's philosophy of history back to "the 'modest language' of rational faith", p. 110).
} 
Erste Einleitung of the third Critique) it is conceived in a weak sense, as a logic-systematic finality: every conceptual totality, as ideas are, constitutes a formally teleological system, insofar as the position of each component is defined according to its relation with each of the other parts and with the whole. This totalizing function is notoriously carried out by the dialectical reason with a merely regulative value, while the material that is systematically organized this way is the object of constitutive knowledge. Yet the way in which constitutive knowledge (itself devoid of systematic relationships, which go beyond the synthesis of experience) joins the rational idea of the totality remains problematic. The junction should be represented by rational principles of "homogeneity", "specification" and "continuity" of nature. Yet these principles, which are themselves purely logic, on one hand can be applied to reality only through as many transcendental principles of reason that prefigure the objective structure of nature. On the other hand, however, they are unable to determine any natural object: not being of intellectual nature, they count only as "heuristic principles" ${ }^{16}$. In 1788 Kant would admit that he had not been clear regarding what authorizes the shift to teleological (regulative) principles, where the causal (constitutive $)^{17}$ laws appear insufficient. These conceptual tensions disappear only in the Critique of Judgment: a stronger conception of finality emerges here, which now receives the dignity of a "transcendental principle" or, more specifically, of the "eautonomous" principle of the power of judgment ${ }^{18}$. In the 'Critique of Teleological Judgment' finality does not only have a logical-systematic character, but rather it assumes a specific organic one: it becomes-within the limits of reflective judgment-an objective finality, intrinsic to natural reality, both in the case that relates in the proper sense to a single organism ("organized natural product"), and in the case that applies analogically to nature as a whole, as "a system following the rule of ends" ${ }^{19}$. Though causal (determinant) explanations and finalistic (reflective) interpretations are never

\footnotetext{
${ }_{17}^{16}$ A 663 = B 691; Critique of Pure Reason, p. 546.

17 Über den Gebrauch teleologischer Prinzipien in der Philosophie, VIII, 160, 20-22.

${ }^{18}$ Cf. J. Peter, Das transzendentale Prinzip der Urteilkraft. Eine Untersuchung zur Funktion und Struktur der Reflektierenden Urteilskraft bei Kant, Berlin-New York, de Gruyter, 1992, pp. 62-65.

${ }^{19} \mathrm{~V}, 376,12$ and V, 379, 2; Critique of Judgement, translated by J. Creed Meredith, Oxford, Clarendon Press, II, pp. 24 and 28.
} 
interchangeable, they are no longer found on two parallel planes, but rather are two aspects of the same reality. In this way, the caesura between efficient causality and final causality is eliminated. Even if the unity between mechanism and finalism comes down to the "supersensible substrate of nature" 20 , mechanical causality works as a function of the overall natural finality and, vice versa, finalistic interpretation never obstructs the path to mechanical explanation, in such a way that the two perspectives (and the two forms of knowledge) integrate. In the Dialectic of pure reason, and in Idea, the two cognitive dimensions of determinant (causal) synthesis and regulative (final) knowledge in some way remain juxtaposed. It is only in the Critique of Judgment (and in subsequent writings on the philosophy of history) that a true convergence of them is realized.

2. Theoretical knowledge and moral judgment - The problem of convergence between causal (constitutive) knowledge and teleological (regulative) knowledge disappears in Kant's works from the first half of the seventeennineties that concern the Kantian concept of history, Über den Gemeinspruch, das mag in der Theorie richtig sein, taugt aber nicht für die Praxis (On the Common Saying; 'This May be True in Theory, but it does not Apply in Practice, 1793) and Zum ewigen Frieden (Perpetual Peace, 1795). In both works the discussion of the historical action of nature is resumed, now identified as Providence itself ${ }^{21}$. Nature and Providence lead history toward its overall finality, using a mechanism that is entirely ascribable to the causal action of empirical phenomena: other than antagonism, which is already invoked in Idea (the "unsocial sociability"), war, linguistic and religious diversity, as well as commercial spirit and power of money are all considered instruments of progress. Yet, according to the theoretical results of the Critique of Judgment, this deterministic point of view, which in individual causal connections requires a determinant knowledge, joins itself with ease to a teleological concept of historical totality, that is aware of its cognitive limits and of its exclusively regulative character. To have faith in the positive function of war for the sake of progress "is no more than a personal opinion

\footnotetext{
${ }^{20} \mathrm{~V}, 422,12-13$; Critique of Judgement, II, p. 82.

${ }^{21}$ VIII, 310, 23; VIII, 361, 4; Political Writings, p. 90; p. 108.
} 
and hypothesis; it is uncertain, like all judgments which profess to define the appropriate natural cause of an intended effect which is not wholly within our control"22. This observation counts for all forms of historical "mechanism". In On Common Saying the principle that human progress "may at times be interrupted, but never broken off " is not theoretically provable, but is acceptable to "assume" as a practical foundation of action until proven otherwise ${ }^{23}$. Perpetual Peace confirms that, being unable to embrace the whole series of determinant causes, human knowledge cannot "observe" (erkennen) the Providence in nature, nor can it "infer (schliessen) its existence" from $\mathrm{it}^{24}$. Yet this perspective, which is "far-fetched" if considered in its theoretical form, where human reason "must keep within the bounds of possible experience", acquires a practical reality as a criterion for bending human sensibility to morals, understood here as the "concept (Pflichtbegriff) of perpetual peace" 25 .

In Kant's works from '93 and '95, another cognitive level emerges alongside theoretical knowledge (composed of regulative and constitutive knowledge entirely reconciled): that of moral judgment. Being practical, this knowledge addresses in primis not the description of history, but rather the action of man in history.

I base my argument upon my inborn duty of influencing posterity in such a way that it will make constant progress (and I must thus assume that progress is possible) and that this duty may be rightfully handed down from one member of the series to the next ${ }^{26}$.

The problem of the philosophy of history continually exceeds the theoretical realm, extending itself into the practical realm in both an anthropologicalpragmatic sense and an expressly moral one. The question here can be left open if historical progress has also a moral character (as On the Common Saying seems to suggest) or only a legal one, thereby favoring the merely exterior conditions - right and culture - for individual moral action (as suggested in the majority of Kantian texts). In any case, the realization of

\footnotetext{
${ }^{22}$ VIII, 311, 35 - 312,1; Political Writings, p. 91.

${ }^{23}$ VIII, 309, 1-2; Political Writings, p. 88.

${ }^{24}$ VIII, 362, 2; Political Writings, pp. 108-109.

${ }^{25}$ VIII, 362, 8-9; 14-15; Political Writings, p. 109.

${ }^{26}$ VIII, 309, 4-10; Political Writings, pp. 88-89.
} 
right, that in the form of the republican constitution and of the federation for peace is a fundamental historical telos, falls under the imperatives of the pure practical reason. Though he never explicitly theorizes this assumption, Kant thinks of a double employment for the same pure practical reason: a specifically ethical employment and a juridical employment ${ }^{27}$. In Perpetual Peace the "doctrine of right" is considered an expression of morality ${ }^{28}$. Anyway, the moral finality (or the juridical-moral finality) of history does not refer to a plain requirement, but rather to the specific form of rational knowledge expressed by the categorical imperative. To say that perpetual peace is a duty ${ }^{29}$, or that universally legislative reason places its absolute veto for war ("Es soll kein Krieg sein",30), or that man must overcome the state of nature and establish a condition of right ${ }^{31}$, is the result of real knowledge. Moreover, this knowledge is constitutive as it is based on a a priori synthesis, despite being immediately expressed by the "fact" of reason and not articulated in transcendental forms.

As a command of the universally legislative reason, the imperative of reason counts a priori and is independent of any empirical condition. As previously stated, it is a practical knowledge that commands an action, not a theoretical knowledge that describes a situation. Nevertheless, morality cannot not have an "interest" in history and in the world. The imperative would lose its meaning without a teleological perspective that shows at least the

\footnotetext{
${ }^{27}$ At least this is the most accredited interpretation. Cf. W. Kersting, Wohlgeordnete Freiheit. Immanuel Kants Rechts- und Staatsphilosophie, Frankfurt am Main, Suhrkamp, 1993, pp. 112-133. The theory of the one and only pure practical root of right and ethics is, nevertheless, challenged by supporters of the Unabhängigkeitstheorie: cf. J. Ebbinghaus, Kant und das 20. Jahrhundert, in Gesammelte Aufsätze, Vorträge und Reden, Darmstadt, Wissenschaftliche Buchgesellschaft, 1968, pp. 111-115 and Die Strafen für Tötung eines Menschen nach Prinzipien einer Rechtsphilosophie, Bonn, Bouvier, 1968, pp. 20-22; G. Geismann, Ethik und Herrschaftsordnung, Tübingen, Mohr, 1974, pp. 56-61 and World Peace: rational Idea and Reality. On the Principles of Kant's Political Philosophy, in H. Oberer (ed.), Kant. Analysen - Probleme - Kritik, Würzburg, Königshausen \& Neumann, 1996, pp. 266-274.

${ }^{28}$ VIII, 383, 21; 384, 32; Political Writings, p. !26, 129.

29 Zum ewigen Frieden, VIII, 362, 9; Political Writings, p. 109. Cf. also Die Metaphysik der Sitten, VI, 355, 2; The Metaphysics of Morals, ed, by M. Gregor, Cambridge, Cambridge University Press, 1996, p. 123.

30 Die Metaphysik der Sitten, VI, 354, 21; The Metaphysics of Morals, p. 123: „there is to be no war".

${ }^{31}$ VIII, 289, 23-28; VIII, 348, 3 - 349, 6; Political Writings, pp. 73, 102.
} 
possibility of its realization. The concept of history presented by Mendelssohn, according to which there is no progress of mankind in history, but rather a continuous, stationary oscillation between advancement and regression, would thwart any moral undertaking of man and would amount to a substantial impossibility of ethics. For similar purposes in the Critique of Practical Reason, after defining the categorical imperative in its absoluteness in the Analytic, Kant maintains in the Dialectic that if the highest good, which joins happiness with morality, "is impossible in accordance with practical rules, then the moral law, which commands us to promote it, must be fantastic and directed to empty imaginary ends and must therefore in itself be false" ${ }^{\text {"32. In }}$ his reflection on history Kant continually argues that the command of morality does not disagree with the philosophical-theoretical knowledge of history. As stated already in Idea, without foreseeing a final era where man's ends are completely developed, "all practical principles" would be destroyed ${ }^{33}$. The fundamental question in Perpetual Peace is: "what does nature do in relation to the end [of perpetual peace] which man's own reason prescribes to him as a duty, i.e. how does nature help to promote his moral purpose (moralische Absicht)?" ${ }^{34}$. If the "guarantee" of perpetual peace, which in the first Supplement is completely entrusted to the nature-providence mechanism, "is not sufficient to enable us to prophesy the future theoretically, it is enough for practical purposes. It makes it our duty to work out our way towards this goal, which is more than an empty chimera" ${ }^{35}$.

In On the Common Saying and in Perpetual Peace the problem of the relationship between different historical knowledge no longer concerns the relation between constitutive and regulative knowledge, which were reconciled in the Critique of Judgment. Rather, it concerns the relation between theoretical knowledge and moral judgment.

On one hand, the fact that in these two works the philosophy of history elaborates a causal-teleological perspective in which the mechanism of nature itself favors the realization of right cannot but sanction the harmonic

\footnotetext{
${ }^{32}$ V, 114, 6-9; Critique of Practical Reason, ed. M. Gregor, Cambridge, Cambridge University Press, 1997, p. 95.

${ }^{33}$ VIII, 19, 13; Political Writings, p. 43.

${ }^{34}$ VIII, 365, 21-23; Political Writings, p. 112.

${ }^{35}$ VIII, 368, 17-20; Political Writings, p. 114.
} 
convergence between theoretical knowledge (in the two forms of determinant and reflective judgment) and moral judgment. In fact, the teleological perspective would not be fully explained, if confined to the realm of theoretical interpretation: its full meaning depends entirely on its projection toward the ethical realm. Natura daedala rerum proves the real possibility of right, favoring the "moral purpose" of men, who would be discouraged from engaging in this obligation, despite being imposed by reason, if this were in fact impossible (ultra posse nemo obligatur).

On the other hand, the problem of integration of the different kinds of historical-philosophical knowledge persists in a different form. The stress of the causal objective moment, that is already present in Idea and resumed in the works from '93 and '95 (though more clearly subordinate to a teleological conception), has as its consequence the acknowledgment of the nonintentional character of human behavior (or at least the majority of it) with regard to the final destination. Historical progress appears as a process in which individual forces and goals become instruments of a collective, unintentional purpose. These instruments are based on an 'eterogenesis of ends' that goes through history, at times clearly opposing itself to human intentions: man wants "concord", nature wants "discord". Kant's adherence to the culture of the Enlightenment, in this case predominantly Anglo-Saxon, persists here too.

Individual men and even entire nations little imagine that, while they are pursuing their own ends, each in his own way and often in opposition to others, they are unwillingly guided in their advance along a course intended by nature. They are unconsciously promoting an end which, even if they knew what it was, would scarcely arouse their interest ${ }^{36}$.

We must look to nature alone, or rather to providence (since it requires the highest wisdom to fulfill this purpose), for a successful outcome which will first affect the whole and then the individual parts. The schemes of men, on the other hand, begin with the parts, and frequently get no further than them. For the whole is too great for men to encompass; while they can reach it with their ideas, they cannot actively influence it, especially since their schemes conflict with one another to such an extent that they could hardly reach agreement of their own free volition ${ }^{37}$.

For if I say that nature wills that this or that should happen, this does not mean that nature imposes on us a duty to do it, for duties can only be imposed by

\footnotetext{
${ }^{36}$ Idee, VIII, 17, 21-26; Idea, in Political Writings, p. 41.

${ }^{37}$ Gemeinspruch, VIII, 310, 21-29; On Common Saying, in Political Writings, p. 90.
} 
practical reason, acting without any external constraint. On the contrary, nature does it herself, whether we are willing or not (fata volentem ducunt, nolentem trahunt) ${ }^{38}$.

Amid theoretical knowledge and moral judgment there is an ineluctable tension, despite the fact that the final result of the historical mechanism collimates exteriorly with moral (or moral-juridical) order. Ethical command cannot leave freedom and good intention (Gesinnung) of the individual out of consideration. On the contrary, the mechanism of nature takes its course entirely independently from individual freedom, even though Kant points out that it does not exclude $i^{39}$. Moral knowledge and causal-teleological knowledge proceed in harmony, but along parallel paths. If in Idea the line of juxtaposition runs along the boundary between causal knowledge and teleological knowledge, the difficulty of finding a point of intersection in the seventeen-nineties concerns the relationship between "theoretical" knowledge in its entirety (which implies the harmonic synergy of causality and finality) and ethical-normative knowledge. In Perpetual Peace the two requirements are treated separately, even in the material organization of the work. The exposition of the articles for peace (preliminary and definitive) includes the ethical-normative dimension; the first Supplement, instead, regarding the "guarantee of a perpetual peace", refers to both the teleological and causal perspective of the mechanism of nature. Even more clearly, in the conclusion of On the Common Saying, after expressing his hope in the efficacy of the juridical (or ethical-juridical) principle that commands the "earthly gods" to work in order to make possible the peace and federation of the people, Kant adds: "I likewise rely (in subsidium) upon the very nature of things to force men to do what they do not willingly choose (fata volentem ducunt, nolentem trahunt) ${ }^{\prime 40}$. In such a philosophy of history Kant does his best to converge, not without difficulty, the requirements of his ethical-juridical thought (to which the status of critical-transcendental thought cannot be refused, despite the many

\footnotetext{
${ }^{38}$ Zum ewigen Frieden, VIII, 365, 28-32; Perpetual Peace, in Political Writings, p. 112.

${ }^{39}$ Cf. Idee, VIII, 17, 7-8; Political Writings, p. 41: history tries to identify a "regular progression" even in "the free exercise of the human will of human will on a large scale"; in Zum ewigen Frieden, VIII, 365, 23-26 (Political Writings, p.112), we find the problem of how nature compels man to do what he ought to do but does not do, "without prejudice to the free agency of man".

${ }^{40}$ VIII, 313, 12-14, my italics; Political Writings, p. 92.
} 
reservations put forward by various interpreters) and the ideology of Enlightenment, in which the idea of progress is founded on the (dogmatic) identity of reason and nature ${ }^{41}$.

3. A point of intersection - These elements of dissonance, or at least of nonresolved juxtaposition, are assuaged in the final work that Kant dedicates to the philosophy of history, Erneuerte Frage: Ob das menschliche Geschlecht im beständigen Fortschreiten zum Besseren sei (An Old Question Raised Again: Is the Human Race Constantly Progressing?), which occupies the second part of The Conflict of the Faculties, 1798. It must be noted, above all, that in this work both 'theoretical' components of historical knowledge endure. It is true that the weight of constitutive knowledge appears to have reduced considerably. In fact, this has caused interpreters (some of them recent) to set the Conflict against $/ d e a^{42}$. Certainly, the hope for knowledge of the overall process of history that is modeled after the motion of the stars and planets (knowledge still yearned for in '84) can be ruled out entirely. To predict the whole historical development means to assume the vantage point of Providence, just as in order to correctly understand the movement of the stars one must assume the vantage point of the sun. Yet if the latter is accessible to man with the help of reason, the former is not within his power, as he cannot apply the "coherency according to natural laws" to the free actions of historical agents. Nevertheless, if it cannot be extended to the determination of the entire course of history, constitutive knowledge does not lose its utility when applied to limited sectors, already available as empirical data. This is clearly suggested by the fact that in The Conflict of the Faculties there is a double

\footnotetext{
${ }^{41}$ For more on these difficulties cf. M. Mori, Aufklärung und Kritizismus in Kants Geschichtsphilosophie, in S. Carboncini (ed.) Die deutsche Aufklärung im Spiegel der neueren italienischen Forschung, Hamburg, Meiner, 1991, ("Aufklärung", V, 1991), pp. 81-102. Refer also to the essay by R. Brandt, Quem fata non ducunt, trahunt. Der Staat, die Staaten und der friedliche Handel, in K.-M. Kodalle (ed.), Der Vernunftrieden. Kants Entwurf im Widerstreit, Würzburg, Königshausen \& Neumann, 1996, pp. 71-86, in which, without going so far as to refer to an inconsistency between critical thought and Enlightenment tradition, Kant's adherence to a philosophy of history is highlighted, where morality and utility (honestum and utile), reason and nature, converge according to an already classical scheme, but refreshed by the (above all Scottish) Enlightenment.

42 Cf. L. Krasnoff, The Fact of Politics. History and Teleology in Kant, "European Journal of Philosophy", II, 1994, pp. 22-40.
} 
reference to the concept of experience-negative in one case, and positive in the other. On one hand, Kant argues that the problem of progress cannot be resolved "immediately" through experience, since this can neither confirm nor refute any of the three alternative possibilities that can describe history as a whole (progress, regress and standstill). Yet in the subsequent paragraph he maintains that "the prophetic history of the human race must be connected to some experience" ${ }^{\mathrm{n}}$, which will be the central argument in the work. In fact, in order to found our predictions about the progress of mankind, "we have only empirical data (experiences)"; that is, we must refer to "the physical cause of our actions as these actually occur as phaenomena" ${ }^{\prime 4}$. In his argumentation, Kant notoriously favors one experience in particular-the enthusiasm produced by the French Revolution on its disinterested spectators. Yet in Kantian gnosiology single experiences do not exist. Each experience is both the cause and effect of other experiences, tightly interwoven in one or more causal series. Only as a totality (this time conditioned, insofar as expressed by an intellectual category) can they effectively constitute true experience. Concentrating the whole argumentation of the essay on experience, even if on one experience, necessarily implies a return of constitutive knowledge, albeit functional to a more ample framework of regulative nature. Only through experience can we reach a solution to the problem of historical progress, though certainly not "immediately", as an object given in sensible intuition, but "mediately", as a survey of causal and constitutive connections that, being projected beyond the boundaries of possible experience, can be indicative of an overall direction.

And so we reach the heart of the work, that is, an argumentation in favor of progress which is quite different from the "guarantee" exhibited in Perpetual Peace. Beyond its explicit finality this argument reveals a new modality in the reciprocal relations between the three forms of historical knowledge previously mentioned. In fact, none of these, considered by itself, can provide a guarantee of progress: constitutive knowledge is certain, but it does not go beyond possible experience; regulative knowledge, on the contrary, encompasses the whole, but does not have a determinant value;

\footnotetext{
${ }^{43}$ VII, 84, 11-12; The Conflict of the Faculties, Abaris Books, New York, 1979, p.151.

${ }^{44}$ VII, 91, 29-31; Conflict, p. 165.
} 
ethical knowledge expresses an exclusively normative, though absolute, dimension. The course of history can, instead, be reached through the synergy of the three forms of knowledge, which now find their actual point of cohesion.

The text that best exhibits the verification of this interpretative hypothesis is the brief $\S 5$, completed by the subsequent $\S \S 6$ e 7 . Though very familiar, the entire paragraph must be cited as it is simple only in appearance.

There must be some experience in the human race which, as an event (Begebenheit), points to the disposition (Beschaffenheit) and capacity (Vermögen) of the human race to be the cause of its own advance toward the better, and (since this should be the act of a being endowed with freedom), toward the human race as being the author (Urheber) of this advance. But from a given cause an event as an effect can be predicted only if the circumstances prevail which contribute to it (welche dazu mitwirkend sind). That these conditions must come to pass some time or other can, of course, be predicted in general, as in the calculation of probability in games of chance; but that prediction cannot enable us to know whether was is predicted is to happen in my life and I am to have the experience of it. Therefore, an event must be sought which points to (hinweise) the existence of such a cause and to its effectiveness in the human race, undetermined with regard to time, and which would allow progress toward the better to be concluded as an inevitable consequence. This conclusion then could also be extended to the history of the past (that it has always been in progress) in such a way that that event would be considered not itself as the cause of history, but only as an intimation, a historical sign (signum rememorativum, demonstrativum, prognostikon) demonstrating the tendency of the human race viewed in its entirety, that, is, seen not as a sum of individuals (for that would yield an interminable enumeration and computation), but rather as divided into nations and states (as it is encountered on earth) ${ }^{45}$.

The first form of knowledge that falls within prophetic history is moral judgment. The cause that is discussed in the first sentence of the paragraph is a moral causality: this is not the mechanical causality of the phenomenal world, but, rather, the noumenal one of beings that act freely, insofar as "authors" (Urheber). Moral nature in this cause is confirmed more than once in the subsequent paragraphs. Man's tendency toward the better, as specified from the very title of $\S 6$, is a "moral tendency". In fact, the occurrence that relates to this - that is, the enthusiastic participation shown by the spectators of the French Revolution-refers, on one hand, to human race as a whole,

${ }^{45}$ VII, 84, 13-35; Conflict, p. 151 
insofar as it is universal, and on the other hand reveals a "moral character (moralischen Charakter)" and a "moral predisposition (moralische Anlage)"46, insofar as it is disinterested. Kant is most likely referring to morality as doctrine of law, as he did in Perpetual Peace, and not specifically to ethics. In fact, he argues that this "moral cause" has two aspects, which concern on one hand a "right" (in this case, the right of all peoples to have their preferred constitution) and on the other hand an "end" which is also a "duty" (but of legal nature), that is, the realization of the republican constitution, the only one that is "just and morally good in itself" 47 . The same goes for the remark for which "genuine enthusiasm always moves only toward what is ideal and, indeed, to what is purely moral, such as the concept of right, and it cannot be grafted onto self-interest"48. But, as previously observed, the presupposition is that the pure doctrine of right arises from the juridical employment of pure practical reason, which has a transcendental value similar to its specifically ethical employment.

Secondly, the paragraph contains a reference to a regulative knowledge. The "disposition" (Beschaffenheit) and the "capacity" (Vermögen) of humanity that allow it to be "the cause of its own advance" suggest a final causality that moves toward a teleological goal, though not specifically defined: that is to say, the complete realization of "those natural capacities which are directed towards the use of his [man's] reason" discussed in Idea, or the institution of the internally and externally perfect constitution, according to Perpetual Peace and the Conflict of the Faculties as well. This causality is entirely free from the conditions of determinant judgment, since on one hand its subject is not an empirical phenomenon, but rather a moral determination, and on the other hand it does not concern a succession of phenomenal causes and effects, but rather the definition of a moral idea; that is, the perfection of mankind (albeit only juridical). As a result, this teleological-moral causality operates "undetermined with regard to time". It cannot be linked to any of the temporal modalities - that is to say, the transcendental schemes

\footnotetext{
${ }^{46}$ VII, 85, 15 and 28; Conflict, p. 153.

${ }^{47}$ VII, 85, 34; Conflict, p. 153.

${ }^{48} \mathrm{VII}, 86,9-10$. For more on the relationship between morality and enthusiasm cf. Gemeinspruch, VIII, 287, 30-34; On Common Saying, in Political Writings, p. 71.
} 
that rule the categories of modality ${ }^{49}$ : not to any given time (it is not only "possible"); not to a specific time (it is not generally translated in a "real" occurrence); and not even to every time (the connection between the cause and the effect that it involves does not have the "necessity" of determinant causality, but is only "inevitable" within the teleological structure of reflective judgment).

Thirdly, $\S 5$ cannot prescind from an implicit reference to determinant knowledge. So far, moral causality has been considered a cause of the advance toward the better that can be represented only in regulative form: this causality does not fall within the determination of empirical phenomena. In order for it to be translated into facts of experience, it needs the cooperation of empirical and sensible causes. In such a way this moral causality can have a phenomenal effect, which is recognizable in the realm of determinant judgment like a link on a necessary causal chain ${ }^{50}$. According to the interpretation that is being proposed, the "circumstances [...] which contribute to it" (die Umstände [...], welche dazu mitwirkend sind), whose realization is indispensible in order to translate the moral cause into an "event", are necessarily empirical contributory-causes - there is always just one moral causality of the noumenal subject. What happened, in Kant's eyes, is that certain facts of experience (the events of the French Revolution, or perhaps even the process of republicanization that followed the Revolution), such as empirical contributory causes along with moral causality, caused the universal and disinterested enthusiasm that can be considered-insofar as an "event"a historical sign of the disposition of mankind toward the better. In other words, the factors of "assistance" came to existence (or the "hindrances" did not) that are the condition of the causal effect of morality in the phenomenal sphere $^{51}$. Moreover, popular participation, insofar as a fact of experience, is not only the effect of a causal empirical series that precedes and conditions it, but in turn also the cause of the series of effects that derive from it. Enthusiasm, though it concerns the spectators only and not the actors of the

${ }^{49}$ Cf. Kritik der reinen Vernunft, A 144-145 / B 184.

50 Cf. Grundlegung der Metaphysik der Sitten, IV, 456, 3-6; Foundation of the Metaphysics of Morals, 2nd edition revised, traslated by L. W. Beck, Upper Saddle River (N.J.), Prentice-Hall, 1997, p. 70.

${ }^{51}$ Cf. Kritik der Urtheilskraft, V, 195, 33-34; Critique of Judgement, p. 37. 
revolutionary events, is not a mere interior sentiment (which would anyway fall under a causal series as an internal phenomenon), but rather the cause of certain external behaviors: in fact, Kant observes that the manifestation of this

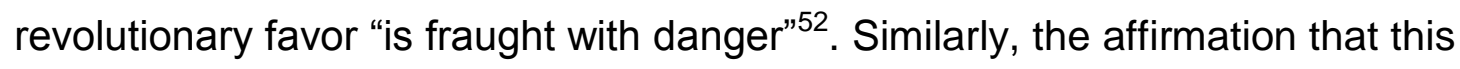
event "is not to be forgotten" ${ }^{\text {"53 }}$, regardless of the outcome of the Revolution, cannot only concern the revelation -or, better yet, the circumstantial evidence - of the moral tendency of humanity. It inevitably refers also to the fact that this event will continue to serve as a model for "new efforts of this kind"; that is to say, for actions in the phenomenal realm of history. From now on it is the cause of an indefinite series of events. Kant believes most likely that the "event" might influence an illuminated despot, in such a way that the process toward the realization of the republican constitution might occur without the need for other revolutions ${ }^{54}$.

Yet there may be need to clarify a point concerning the relation between the empirical "event" of the emotive participation in the Revolution (and the inevitable phenomenal causal network in which it is involved) and the moral cause of the progress of mankind. Projected onto history in general, past and future, the "event" is not a "cause" of progress, but simply its "historical sign": it cannot have but a circumstantial value, because there is, in general, obviously no connection in terms of cause and effect between a particular empirical fact and the general orientation of history, which implies the series of events prior to it as well ${ }^{55}$. But if the event is seen as concerning the particular historical moment of which Kant does have experience, what in fact occurs is a particular causal connection. Enthusiasm in this case is not only the sign, but rather the actual effect of moral cause, which entwined itself with other empirical contributory-causes at that particular junction. Obviously, this causal connection is not certain, since the effect of moral causality in the

\footnotetext{
${ }^{52}$ VII, 85, 27; Conflict, p. 153.

${ }^{53}$ VII, 88, 12; Conflict, p. 159.

${ }^{54}$ Cf. VII, 87, 11-14 / 88, 1-7; Conflict, pp. 157-59.

55 I think that R. Brandt's theory, according to which there has been progress in history starting from the French Revolution, is not sustainable on the basis of textual evidence (R. Brandt - W. Stark (eds.), Zum Streit der Fakultäten, in Neue Autographen und Dokumente zu Kants Leben, Schriften und Vorlesungen, Hamburg, Meiner, 1987, p. 39).
} 
sensible world, though certain, remains inexplicable in its modalities ${ }^{56}$. But the event's aptitude to refer (hinweisen) to moral disposition directs us to presume that the event be the effect of morality. Indeed, if a moral consequence were not to be displayed in it, that event would be devoid of meaning to the aim of the advancement of mankind towards the better. In this way the occurrence of enthusiasm is on the point of convergence between the series of phenomenal causes and the moral causality, where the latter crosses the former without interrupting it. In $\S 5$ Kant refers to three types of causalities: 1) a noumenal causality through which moral disposition produces the event of enthusiasm; 2) a final causality through which this very disposition is the cause of the advancement of mankind toward the better; 3 ) an efficient and phenomenal causality whereby the "event" is, on one hand, the effect of revolutionary events (the phenomenal contributory-causes) and, on the other hand, the cause of additional philo-revolutionary behaviors. Three types of knowledge respectively correspond to these three causes: 1) moral judgment, that expresses the categorical imperative; 2) regulative knowledge, especially in the form of reflective judgment; 3) constitutive knowledge, in the form of transcendental synthesis of experience and of determinant judgment.

The guarantee of progress results from the synergy of all three forms of knowledge. Moral judgment assures us that man is able to "act" morally, which means on the one hand to have good will, and on the other to turn this will into a moral phenomenal effect ${ }^{57}$. Only reflective judgment (regulative knowledge) can project this ability from the individual to mankind, turning an individual moral certainty into a practical (regulative) idea of history as progress. In the end, only determinant knowledge can verify the actual realization of the ethical-teleological perspective in the reality of history, though limited to fragments of causal series. Yet this confirmation of normative and regulative knowledge by constitutive knowledge, that is, this confirmation of the idea by experience (though fragmentary), constitutes the

\footnotetext{
${ }^{56}$ Cf. Religion, VI, 170, 30-38; Religion within the Boundaries of Mere Reason. And Other Writings, edited by A. Wood and G. di Giovanni, Cambridge, Cambridge University Press, 1998, p. 166.

${ }^{57}$ Cf. for example Kritik der Urtheilskraft, V, 195, 22-24, where the possibility for an action of the supersensible over the sensible is already found "in the concept of a causality by freedom, the operation of which, in conformity with the formal laws of freedom itself, is to take effect in the world" (Critique of Judgement, p. 37).
} 
real foundation of the evidence. This evidence, in a way, has circumstantial value (as an "historical sign") for the future, whereby experience cannot yet provide the knowledge of those physical contributory-causes that allow for the moral cause to turn into historical reality. On the other hand it has definitive value regarding the present, because the moral disposition shown by the occurrence of enthusiasm "not only permits people to hope for progress toward the better, but is already itself progress in so far as its capacity is sufficient for the present" ${ }^{\prime 58}$.

4. History and Experience - The reference to experience as confirmation of progress is not an irrelevant aspect of Kantian philosophy of history. Already in Idea Kant had made reference to this function, pointing out that only " $a$ little" (etwas Weniges) of the purposeful natural process is revealed in experience $^{59}$. In On the Common Saying he claims there is "various evidence" (manche Beweise) that mankind in its entirety is advanced when compared to the past ${ }^{60}$. Similarly Das Ende aller Dinge (The End of All Things) states that there are "experimental proofs (Erfahrungsbeweise) of the superior morals of our age as compared with all previous ones"61. In each of these cases, though, Kant fails to clarify what "experience" or "evidence" or "proof" consists of-the term Beweis is most likely used in a very weak and generic sense. Only in The Conflict of the Faculties the "experience" that confirms the progressive character of history becomes a specific fact.

Yet there remains another more important difference between the work from 1798 and the previous ones. Up until '98 experience served to ascertain the empirical causal connections (regularities of social phenomena, effects of antagonism, consequences of war, etc) that provided the structure for the nature-providence mechanism and, therefore, for history. At times, as in Idea, experience is put into relation with the possibility of starting from a partial constitutive knowledge and arriving at the determination of the entire system, even if with the same uncertainty with which certain astronomical

\footnotetext{
${ }^{58}$ VII, 85, 17-18; Conflict, p. 153.

${ }^{59}$ VIII, 27, 11-12; Political Writings, p. 50.

${ }^{60}$ VIII, 310, 4-6; Political Writings, p. 89.

61 VIII, 332, 18-20; The end of all things, in Religion within the Boundaries of Mere Reason. And Other Writings, p. 199.
} 
observations allow us to determine "the path which our sun with its whole swarm of satellites is following within the vast system of the fixed stars" ${ }^{\prime 2}$. In other instances, as in On the Common Saying (or The End of All Things, or Perpetual Peace), empirical evidence has to do with the guarantee of the moral progress of mankind. Yet in both cases progress depends on the existence of a "mechanism" of nature, conceived of both cognitively and morally, which enables us to arrange the multiplicity of occurrences into a systematic whole. In The Conflict of the Faculties, on the other hand, the reference to the nature-providence mechanism-which is only mentioned once in $\S 10$-is overlooked, and this interest in the systematic character of history is attenuated. Considered experience, that is to say, the disinterested participation in the French Revolution, does not aim at finding segments of causal series confirming the consistency of historical-natural order with moral one, but rather at recognizing an empirical effect of the moral causality which founds progress. Through the effects unfurled in reality empirical knowledge demonstrates the existence of a moral causality of mankind and its realization in the historical world on certain conditions.

This is not to say that the element of mechanical causality disappears in the Conflict of the Faculties. When asking himself what comprises the advance toward the better, Kant responds: "Not an ever-growing quantity of morality with regard to intention, but an increase of the products of legality in dutiful actions whatever their motives"63. Despite the fact that Kant's position regarding this point appears to oscillate, the solution in the Conflict is clear. Humanity cannot become morally better, since it cannot enhance its own potential for morality. Instead the phenomenal effects of its moral causality, that is the legal behaviors, continue to increase; through the causal mechanism, they enter a virtuous circle in which each of them causes a series of phenomena of increasing legality. Just as the unforgettable enthusiasm for the Revolution will not lack positive empirical effects by influencing future behaviors, each externally moral action will be an empirical (and mechanical) cause of a growing number of legal behaviors. We will continue to behave better not for moral reasons, but "partly out of love of honor, partly out of well-

\footnotetext{
62 VIII, 27, 17-19; Political Writings, p. 50.

${ }^{63}$ VII, 91, 22-25; Conflict, p. 165.
} 
understood self-interest" ${ }^{\prime \prime 4}$. This amelioration will be the consequence of the moralischer Zwang, which by no means requires "that all men be virtuous: it is only necessary that the mere habit of showing public respect for morality be realized" ${ }^{65}$. The exterior conduct of man will continue to be better, "when one will no longer achieve honors, social relations, offices or even a wife without rectitude and without the external signs of good intention"66. It is in no way possible to predict when the causal morality of humanity will intervene in history (as it occurred in the Revolution), since this falls outside of temporal determinations. But when it does occur-that is, when the "circumstances" that are empirical contributory-causes will be present-a new causal series of legal phenomena will enter history multiplying their effects. Each irruption of morality in history has as its effect an increment of phenomenal legality, though the reverse certainly does not hold true: the largest diffusion of legality will perhaps favor moral behaviors but will not be their cause, since ethical choice can come about only out of the abysses of noumenal autonomy.

It has been thought that Kant's later lost of interest for the systematic aspect of history entails the risk of a regression in dogmatism, because only a completely teleological-systematic perspective corresponds to the requirements of critical philosophy ${ }^{67}$. Yet for me the opposite seems to hold true. The regulative nature of ideas of pure reason or of reflective judgment allows for a systematic representation of history (with a few problems in the Critique of Pure Reason, with greater theoretical consistency in the Critique of Judgment), but it denies this concept any cognitive value. Therefore, to the extent that Kant wants to use it as a "guarantee" of progress (and not as a simple indication of non-impossibility), as his Enlightenment culture and many of his works would suggest, the risk of a dogmatic utilization of it necessarily emerges. This way the Kantian theory of Nature-Providence continues to remain suspended between a regulative perspective that does not guarantee and a guarantee that cannot have a critical foundation. Vice versa in The Conflict of the Faculties_-by analogy with the normativity of many pages in

\footnotetext{
${ }^{64}$ VII, 92, 1-2; Conflict, p. 167.

${ }^{65}$ Reflexion 1394, XV, 607.

${ }^{66}$ Reflexion 1393, XV, 606.

${ }^{67}$ This hypothesis was developed by P. Kleingeld, Fortschritt und Vernunft, p. 80.
} 
The Doctrine of Right-historical progress is entrusted above all to the assumption, perfectly consonant with the criticism, that moral causality acts in history. This causality will certainly unfold in the world, giving a general sense to the course of history: yet how and when cannot be predicted. The systematic design is not excluded but, rather than being a presupposition that gives a sense to history, it is the consequence of the fact that history, where moral causality works, has a sense.

According to the work from ' 98 experience tells us that this sense is not an illusion. In other words, the guarantee of historical progress is no longer sought outside of the world, in a teleological dimension of nature's design that either is dogmatic or guarantees nothing at all. Only in the actual world, where history is realized, the guarantee of progress, that the practical reason commands and the teleological reason prefigures, can be found, though in fragments of experience. Even if, empirical knowledge in turn, always limited to a small portion of reality, cannot seize the overall direction of historical progress without the aid of moral judgment, which dictates how history should be, and of teleological judgment, which shows how history might be. To paraphrase Kant himself, if we consider their function in the philosophy of history separately, moral knowledge and teleological knowledge are empty, and empirical knowledge is blind. 